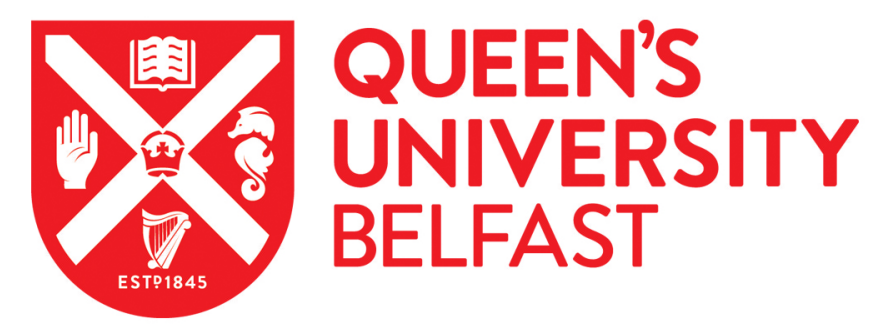

\title{
Utilizing crude waste glycerol in the bio refinery: glycerol gels for in situ substrate delivery to whole cell biocatalysts.
}

Bothwell, K. M., Krasňan, V., Lorenzini, F., Rebros, M., Marr, A. C., \& Marr, P. C. (2019). Utilizing crude waste glycerol in the bio refinery: glycerol gels for in situ substrate delivery to whole cell biocatalysts. ACS Sustainable Chemistry \& Engineering. https://doi.org/10.1021/acssuschemeng.9b00891

Published in:

ACS Sustainable Chemistry \& Engineering

Document Version:

Peer reviewed version

Queen's University Belfast - Research Portal:

Link to publication record in Queen's University Belfast Research Portal

Publisher rights

(c) 2019 American Chemical Society.

This work is made available online in accordance with the publisher's policies. Please refer to any applicable terms of use of the publisher.

\section{General rights}

Copyright for the publications made accessible via the Queen's University Belfast Research Portal is retained by the author(s) and / or other copyright owners and it is a condition of accessing these publications that users recognise and abide by the legal requirements associated with these rights.

Take down policy

The Research Portal is Queen's institutional repository that provides access to Queen's research output. Every effort has been made to ensure that content in the Research Portal does not infringe any person's rights, or applicable UK laws. If you discover content in the Research Portal that you believe breaches copyright or violates any law, please contact openaccess@qub.ac.uk. 


\title{
Utilizing crude waste glycerol in the bio refinery: glycerol gels for in situ substrate delivery to whole cell biocatalysts.
}

\author{
Kyra M. Bothwell, ${ }^{a}$ Vladimír Krasňan, ${ }^{b}$ Fabio Lorenzini, ${ }^{a}$ Martin Rebroš, ${ }^{b^{*}}$ Andrew C. Marr, ${ }^{a^{*}}$ \\ and Patricia C. Marr ${ }^{\mathrm{a}^{*}}$ \\ a Institute of Biotechnology, Slovak University of Technology, Radlinského 9, 81237, Bratislava, Slovakia. \\ b School of Chemistry and Chemical Engineering, Queen's University of Belfast, David Keir Building, Stranmillis Road, \\ Belfast BT9 5AG, United Kingdom. \\ p.marr@qub.ac.uk \\ a.marr@qub.ac.uk \\ martin.rebros@stuba.sk
}

Supporting Information: Materials and methods, bacteria cultivation experiments.

Synopsis. Glycerol gels provide a method of delivering glycerol to biocatalysts without the need for glycerol pre-purification.

Keywords: crude glycerol, in-situ substrate delivery, whole cell biocatalysts, sol-gel immobilization, 1-3, propanediol.

\begin{abstract}
Sol-gel methods were used to facilitate the in-situ controlled delivery of glycerol as a substrate for whole cell biocatalysis. The entrapment of the polyol within a silica gel matrix enabled the utilization of crude and moderately toxic bio-derived substrates that could not be used in fed-batch mode. Different grades of glycerol were incorporated in gels and fed to C. butyricum for 1,3-propanediol production and E.coli for recombinant protein production. Of particular note was the successful use of crude glycerol gels with E.coli. By virtue of gel immobilisation, previously toxic crude glycerol samples were rendered active; and the use of gel technologies was therefore shown to expand the range of biomass that can be utilised in whole cell biocatalytic processes. Specific matching of the acid used in the gel synthesis with the fermentation medium further supported cell growth.
\end{abstract}




\section{Introduction}

Biocatalysts can be very susceptible to poisoning, or the suppression of activity, by toxic impurities in the substrate. Impurities are common in bio-derived feedstocks, and can vary significantly from batch to batch. This can require the use of low substrate concentrations, as the substrate feed must be diluted down, or in extreme cases prevent the use of the biotransformation altogether. Dilution leads to a substantial increase in process costs, as the products must be separated from the aqueous waste. The production of high volumes of wastewater is not environmentally acceptable and therefore the aqueous waste must go into recycling, significantly increasing processing steps. For these reasons the development of strategies to allow the use of impure substrates and/or more concentrated fermentation broths are key factors in the expansion of biocatalysis technologies.

There are several approaches employed to mitigate these problems; for instance, protection of biocatalysts by immobilization. ${ }^{1,2,3}$ biphasic systems, ${ }^{4,5,6}$, or the application of biocatalysts in non-conventional media. However, most of these methods require modification of the biocatalyst itself, or require the use of non-environmentally friendly solvents, both of which can reduce activity and / or selectivity.

In an effort to increase the substrate scope of our biocatalysts, we investigated the application of biocompatible gels for substrate delivery. These gels contain the substrate within a solid matrix, which gives them the potential to retain impurities locked inside, whilst delivering the substrate in situ. If the matrix has a higher affinity for undesirable impurities than the desired substrate, the matrix will act as the toxic substrate binder. The gels were made using three components; silica, glycerol and a biocompatible acid such as citric or tartaric acid.

Crude glycerol is a waste product from the production of biodiesel. Biodiesel is produced by the transesterification of triglycerides into fatty acid alkyl (usually methyl) esters in the presence of an alcohol, with an acid, base or enzymatic catalyst. ${ }^{7}$ The most common method of biodiesel synthesis is catalysed by a homogeneous base (Scheme 1); after the process the base is retained in a crude glycerol-containing phase which spontaneously separates from the biodiesel. Biodiesel is of particular interest as it can be produced from waste cooking fats and oils, and the huge quantities of waste fats and oils produced from industrial sources are challenging to dispose of ${ }^{8}$ Crude glycerol is generated at about $10 \%(w / w)$ of biodiesel $^{9}$ 
and is produced with varying purity. The production of biodiesel has increased significantly in the past few decades. ${ }^{10,11,12}$

The disposal or purification of crude glycerol is comparatively expensive, ${ }^{13}$ making these raw material management routes economically as well as environmentally unfavourable. A convenient solution as explored here would be to utilise non-purified (crude) glycerol for the production of useful chemicals via fermentation processes. The development of new technologies that allow for the efficient use of crude glycerol will therefore support the commercialization and increase the sustainability of biodiesel production.

Glycerol is a useful raw material for the production of value added chemicals, in particular through bioconversion by microbial fermentation. A number of such promising applications include conversion to 1,3-propanediol, ${ }^{9,10,14-16}$ succinate, $^{17}$ ethanol, ${ }^{18,19}$ butanol $^{20}$ and hydrogen. ${ }^{21}$ The product of interest in this study is 1,3-propanediol, as we have shown that 1,3-PD can be converted into a range of value-added chemicals in downstream chemocatalytic hydrogen borrowing reactions. ${ }^{14,15,22,23}$

In previous studies Clostridium butyricum represented the most promising 1,3-propanediol producer among the Clostridia genus. ${ }^{24}$ The main advantages of the species are higher 1,3PD yields (up to $0.64 \mathrm{~mol} / \mathrm{mol}$ of glycerol) ${ }^{9}$ and shorter fermentation times. In addition, compared to other 1,3-PD producers (e.g. C. frendii, K. penumonie), glycerol dehydratase of C. butyricum (enzyme from glycerol - 1,3-PD pathway) doesn't require coenzyme $B_{12}$, which represents a significant economic benefit. ${ }^{25,26}$<smiles>[R]C(=O)OCC(COC([R])=O)OC([R])=O</smiles>
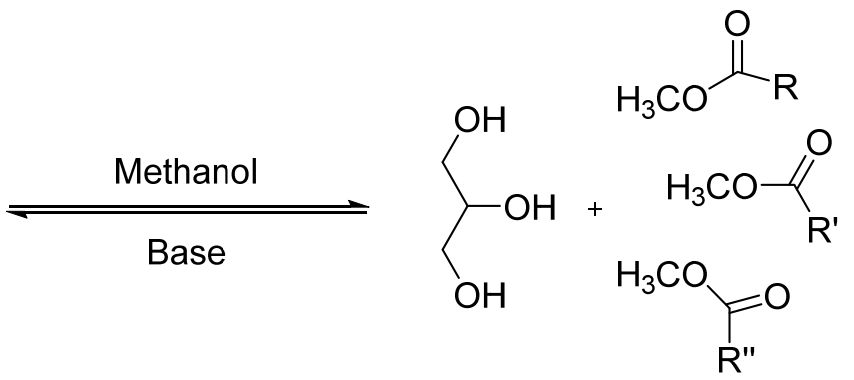

Scheme 1. Alkaline catalysed transesterification of fats and oils to produce biodiesel and glycerol.

There are many microorganisms that can utilise glycerol as an energy source due to the natural occurrence of glycerol in nature. ${ }^{27,28}$ Traditionally carbohydrates such as sugars and starches are used in industrial fermentation processes, thus competing with the food chain. 
The use of a waste material such as crude glycerol could be considerably cheaper, more ethical and more environmentally friendly. ${ }^{21}$ However, without purification, the use of crude glycerol in biocatalytic fermentation can be a challenging process, due to the myriad of impurities present..$^{21}$ The composition of crude glycerol can vary depending on the feedstock and the method of transesterification, ${ }^{29}$ but the main impurities are free fatty acids, inorganic salts and methanol. ${ }^{10}$ Many studies have shown that the existence of these impurities has an inhibitory effect on microbial growth. ${ }^{10,30-33}$

The presence of impurities in substrates derived from biomass can supress whole cell biocatalysis, or even kill the microbes. High substrate concentrations can also be detrimental to the reaction at concentrations that are considered normal in chemocatalysis. Typically, fermentation reactions occur at very dilute concentrations to avoid poisoning the biocatalyst.

Most production processes for fermentation fall into three categories: batch, fed-batch and continuous. $^{34}$ Batch fermentation suffers from continually decreasing concentrations of substrate, with increasing biomass and product concentrations. Continuous fermentation processes typically have a constant biomass and product concentration, where the substrate is a constant although at growth-limiting concentrations. This gives a controlled growth rate; however, it does not result in optimum conditions. Under these conditions any impurities in the substrate will build up over time. In fed-batch fermentation, certain substrates are added as necessary during the process, often maintaining optimal substrate concentration for the maximum production of product, under these conditions impurities, products and side products accumulate. The most common way to attempt to regulate substrate concentration is to supply a steady feed. Our approach, the entrapping of the substrate in a matrix offers the additional benefits of controlled delivery of the substrate and retention of unwanted impurities within the material.

In this study glycerol gels were synthesised via the sol-gel process to explore the potential of immobilised glycerol silica gels as a substrate delivery system for glycerol. In systems using bacteria which feed on glycerol to produce value added chemicals, the limiting factor for the reaction can often be the necessity for a very dilute system with a low concentration of glycerol. Too high a concentration of glycerol can poison the bacterial cells and inhibit the reaction. Therefore, the gel was designed to deliver glycerol into the solution gradually over 
a period of time. The glycerol chosen for immobilisation was from three different sources and with different levels of purity. A secondary aim was to investigate the effects of immobilisation of the glycerol on the impurities present in the glycerol samples. The gels were made using glycerol as the template in a one-pot low temperature silica gel synthesis by the sol-gel method.

\section{Results and discussion}

Several different grades of glycerol were trialled for entrapment within $\mathrm{SiO}_{2}$ gel matrices, to create materials for glycerol delivery into bacterial cultures (S.I. S1 materials and methods). Glycerol samples that were successfully incorporated into a silica gel included pure glycerol P (99.5 \% purity), industrial glycerol I (97 \% purity) and crude glycerol C (76.9 \% purity). The gels were formed by mixing glycerol with an acid catalyst in ethanol, followed by the addition of Tetraethoxy orthosilicate (TEOS). The gels were aged for over 4 weeks before use. Natural acids (citric, tartaric) were employed as the acid catalysts of gelation, these were chosen to maximise the compatibility of the resultant materials with bacterial cultures, as biological organisms are typically sensitive to acids and $\mathrm{pH}$ changes. The amount of acid added was limited by the solubilities of the acids in the ethanol/glycerol/TEOS mixture.

\section{Synthesis of glycerol gels}

Synthesis of pure glycerol (P) gels: Stable gels were found to form with glycerol (e.g. Figure 1), ethanol and TEOS (glycerol:TEOS 1:1) containing various quantities of each acid. Citric acid (CA), and L-(+)-tartaric acid (TA) catalysed glycerol gels typically gelled in 8-16 hours. Further experimental details are available in the S.I. (S1.2).

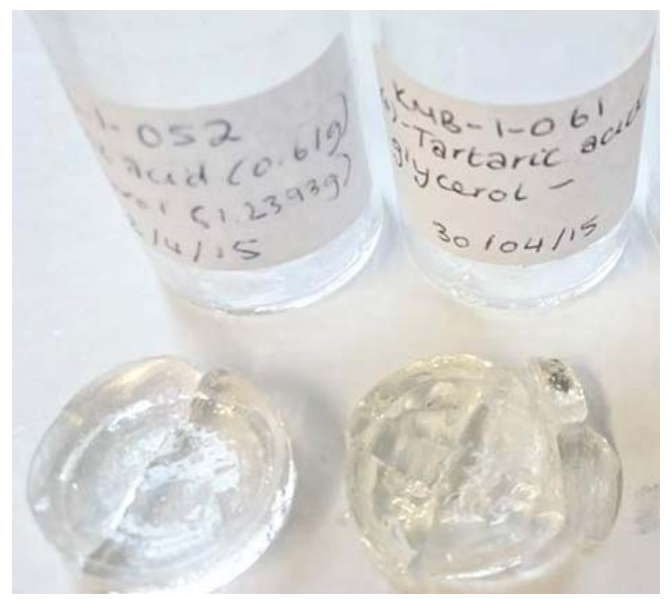

Figure 1. Glycerol gels made using (left) citric acid, (right) L-(+)-tartaric acid 
The acids had different solubilities in the glycerol/TEOS/ethanol mixture and the amount of each acid added was tested to saturation. Citric acid and L-(+)-tartaric acid could be dissolved in sufficient quantity to catalyse the gelation and form a stable silica gel.

Synthesis of industrial glycerol (I) gels: These gels were prepared in a similar manner to the pure glycerol gels (S.I. S1.3). The gels had a very similar appearance to the pure glycerol gels, although a light yellow colour was observed, the colour originated from the impure glycerol. Synthesis of crude glycerol (C) gels: Crude glycerol was entrapped by both citric and L-(+)tartaric acid catalysed sol-gel techniques, using the same methods used for pure (P) and industrial (I) glycerol (S.I. S1.4). The synthesis of these gels was initially hindered by the low solubility of the crude glycerol in the TEOS/ethanol mixture, glycerol $\mathbf{P}$ and $\mathbf{I}$ were both transparent and viscous liquids, glycerol $\mathbf{C}$ was a semi-solid, opaque and dark brown in colour (Figure 2).

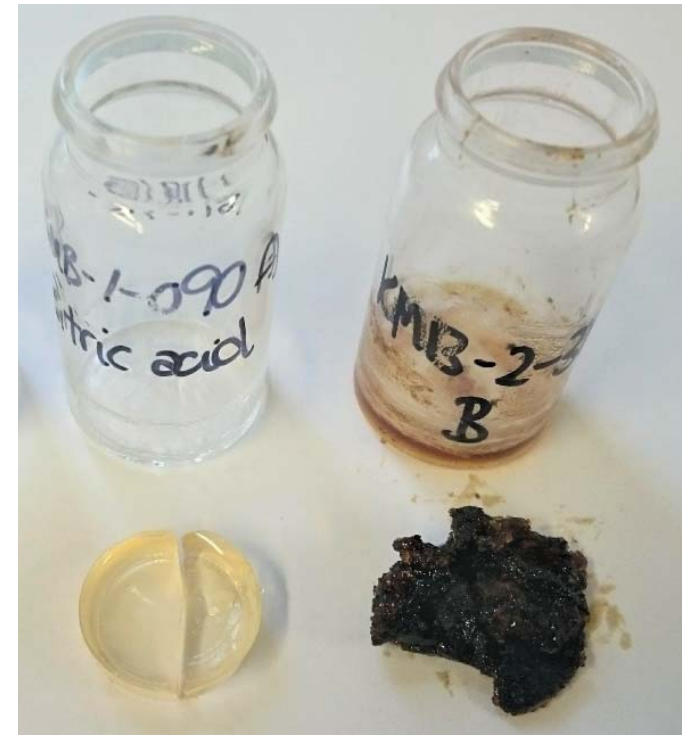

Figure 2. Left to right: comparison of I (LHS) and C (RHS) glycerol gels.

A standard 1:1:1 ratio of TEOS, glycerol and ethanol, as used in the synthesis of glycerol I gels, appeared to leave some unincorporated crude glycerol when the gel formed, creating a non-homogenous gel with sections of non-fully entrapped glycerol (Figure 2 RHS). The relative proportions of glycerol and ethanol were varied in order to maximise incorporation of the crude glycerol within the silica matrix. The most stable glycerol gels were selected for further study (S.I. S2.1 Tables S3-5). 


\section{Glycerol release to biocatalytic bacteria}

Glycerol gels containing different purities of glycerol (P, I and $\mathbf{C})$ and catalysed by tartaric or citric acid, (S.I. Tables S3-5), were used to feed glycerol to bacteria within fermentation broths, (Figure 3). The fermentation media provide the bacteria with a nitrogen source, water, various salts, and micronutrients optimised to support cell growth. The fermentation media for $C$. butyricum and E.coli are referred to as Y5 medium and semi-defined medium respectively, (S.I. S2.2, S2.3).

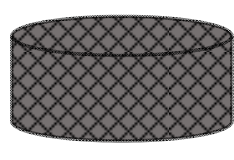

Silica glycerol gel:

made with crude glycerol

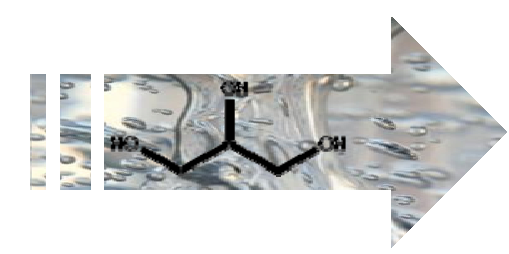

Glycerol release providing purified

Glycerol

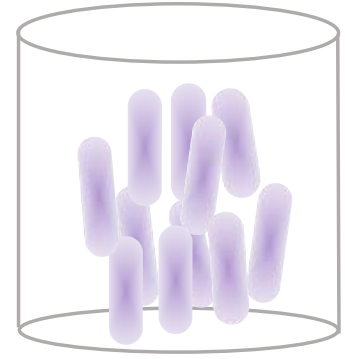

Utilization of

purified glycerol

by bacteria

Figure 3. Schematic of glycerol delivery

The dissolution of glycerol from the glycerol gels took place in the liquid phase fermentation media for C. butyricum and E. coli and was measured by HPLC. Control experiments used a fermentation medium that contained non-immobilised pure glycerol at concentrations approximately equal to the amount contained within the glycerol gels. The micro-cultivation experiments were carried out in 96 well microtest plates, with a working volume of $200 \mu \mathrm{L}$. The gels were weighed into each well before being exposed to UV light for 12 hours in a laminar chamber for UV sterilisation to prevent contamination before cultivation. The specific media (E. coli or C. butyricum) was pipetted into the wells, followed by inoculation with the bacterial cells, which were then cultivated for 16 hours. The optical density at $600 \mathrm{~nm}$, an indication of cell growth, was measured every 5 minutes, and after cultivation $\mathrm{pH}$ was measured in each well samples, which were then submitted for HPLC analysis. 


\section{The use of glycerol gels to feed $C$. butyricum}

C. butyricum can be used to convert a biomass feed to a renewable platform chemical. Testing focussed on the comparison of gels containing glycerol I and $\mathbf{C}$ as the purification of glycerol to a high purity (P) would not be commercially viable, given the relatively low value of chemical products obtained.

Release of glycerol I into the C. butyricum medium: Dissolution experiments were carried out to observe glycerol release into the Y5 medium from immobilized glycerol I gels, (Figure 4). The dissolution of glycerol from the gels into the Y5 medium showed similar patterns to the dissolution into water, so it can be assumed that the other non-water components of the Y5 medium do not significantly interfere with the glycerol delivery. The L-(+)-tartaric acid catalysed gels gave the highest release of glycerol. The slight differences seen between the parallel experiments for both the citric acid and L-(+)-tartaric acid gels (CA-A, CA-B and TA-A, TA-B) were due to the slightly different amounts of glycerol per gel (S.I. Table S4). The difference observed between the citric and the L-(+)-tartaric acid methods of gelation can be explained by the differences in the total weight of each gel used, as the citric acid catalysed gels had a lower wt \% of glycerol.

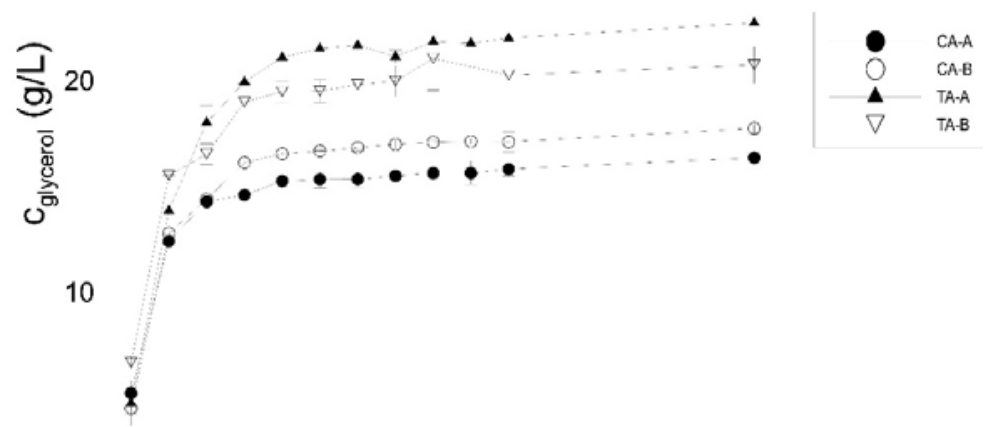

0 $\begin{array}{lllll}0 & 2 & 4 & 6 & 8\end{array}$

Figure 4. Glycerol concentration released from glycerol I gels to the C. butyricum media per time. Two duplicates of each type were tested. Conditions: $35{ }^{\circ} \mathrm{C}, 250 \mathrm{RPM}$, reaction volume $1 \mathrm{ml}$, gel concentration $40 \mathrm{~g} / \mathrm{L}$. 
The change in $\mathrm{pH}$ was also monitored over time as the glycerol was released from each gel, as the gels contain a significant amount of acid (citric or tartaric) which could be released alongside the glycerol and disrupt the optimum $\mathrm{pH}$ conditions for the bacterial cultures. The glycerol gels were tested in the $\mathrm{Y} 5$ medium and the $\mathrm{pH}$ was set to 9.0 and 8.5 for CA and TA gels respectively (before sterilization by $\mathrm{NH}_{3}$ ). Two parallels from each type of gel and two blanks were tested. The Y5 media with different $\mathrm{pHs}$ were also measured as blanks to observe the effect of sterilization on the $\mathrm{pH}$ values (without gel addition, Figure 5). Within the first half hour the $\mathrm{CA}$ and TA gels gave a sharp decrease in $\mathrm{pH}$, this settled after two hours. This pattern was also seen in glycerol dissolution into water experiments, as the maximum release of glycerol is seen within the first two hours. The decrease in $\mathrm{pH}$ was significantly larger for the CA gels, which is expected as these gels had $3.2 \mathrm{mmol}$ of acid per gel whilst the L-(+)-tartaric acid catalysed gels only contained $2.2 \mathrm{mmol}$ of acid.

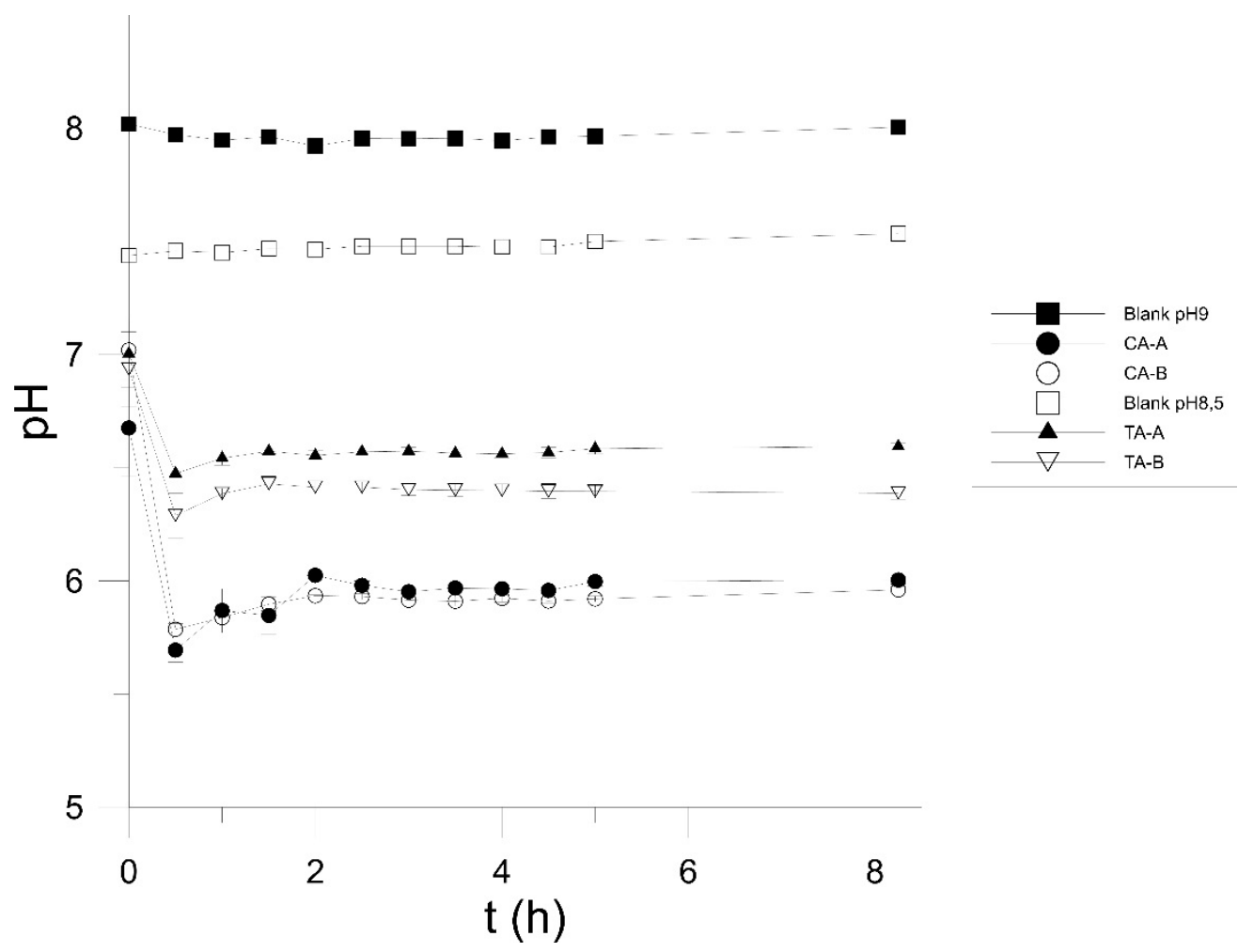

Figure 5. $\mathrm{pH}$ change in $\mathrm{Y} 5$ medium against time for Glycerol I gels in the C. butyricum medium at $35^{\circ} \mathrm{C}, 250 \mathrm{RPM}$, reaction volume $1 \mathrm{ml}$, gel concentration $40 \mathrm{~g} / \mathrm{L}$.

Cultivation of $C$. butyricum using glycerol I gels: To counteract the $\mathrm{pH}$ decrease in the $C$. butyricum cultivation media, caused by the addition of the gels, different $\mathrm{K}_{2} \mathrm{HPO}_{4}$ and $\mathrm{KH}_{2} \mathrm{PO}_{4}$ concentrations were tested as $\mathrm{pH}$ buffers. The optical density (final $\mathrm{OD}_{600 \mathrm{~nm}}$ ) was 
measured by microplate spectrophotometer to determine the increase in biomass by the end of the experiment (Table 1). The specific growth rate is then inferred from the optical density. For all the conditions tested $C$. butyricum bacteria were able to utilize the glycerol released from the gels and produce 1,3-propanediol, although productivity varied in comparison to the control reaction, which contained a fixed concentration of glycerol added at the start.

The gel concentration was set at $40 \mathrm{~g} / \mathrm{L}$ to achieve approximately $15-20 \mathrm{~g} / \mathrm{L}$ dissolution of glycerol, and the control reaction was the $Y 5$ medium with $20 \mathrm{~g} / \mathrm{L}$ of pure glycerol added at the beginning. CA-A; CA-B and TA-A gels were all biocompatible with $C$. butyricum to some degree. At the 5:5 and 10:0 concentration of $\mathrm{K}_{2} \mathrm{HPO}_{4}: \mathrm{KH}_{2} \mathrm{PO}_{4}$ buffer $(\mathrm{g} / \mathrm{L}: \mathrm{g} / \mathrm{L})$ the control reaction utilised a higher proportion of glycerol to produce a higher quantity of 1,3-PDO in comparison to the citric acid and L-(+)-tartaric acid gels tested (S.I. Table S6). At the 15:0 concentration of $\mathrm{K}_{2} \mathrm{HPO}_{4}: \mathrm{KH}_{2} \mathrm{PO}_{4}$, with the TA-A gel, the performance of the homogeneous and gel-fed reactions was very similar. The bacteria utilised $16.01 \mathrm{~g} / \mathrm{L}$ of glycerol to produce $4.10 \mathrm{~g} / \mathrm{L}$ of 1,3-PDO, compared to the control reaction where $16.59 \mathrm{~g} / \mathrm{L}$ glycerol was utilised to produce $4.36 \mathrm{~g} / \mathrm{L} 1,3-\mathrm{PDO}$. At $20: 0 \mathrm{~K}_{2} \mathrm{HPO}_{4}: \mathrm{KH}_{2} \mathrm{PO}_{4}$ the two glycerol gels performed noticeably differently; the CA-B gel utilised $11.12 \mathrm{~g} / \mathrm{L}$ glycerol to produce $4.10 \mathrm{~g} / \mathrm{L}$ of 1,3propanediol, whilst the TA-A gel out-performed the control experiment utilising $16.34 \mathrm{~g} / \mathrm{L}$ glycerol and producing $5.59 \mathrm{~g} / \mathrm{L}$ of 1,3-propanediol. In general specific growth rates and final ODs were lower for gel-fed reactions compared to the control reaction, indicating slower cell metabolism. This could be caused by inhibition arising from the gels themselves, or a result of the high concentrations of phosphates from the buffers.

The TA-A gel was the best performing glycerol I gel, able to produce more 1,3-PDO than the citric acid catalysed gels CA-A and CA-B. The higher molar quantities of acid used to create the citric acid gels, and the higher weight percent of glycerol in the TA-A gel $(20 \mathrm{~g} / \mathrm{L}$ compared to $15 \mathrm{~g} / \mathrm{L}$ ) (Figure 4) may contribute to this. Another factor was highlighted by Krysteva and co-workers, ${ }^{35}$ who used wine vinasse containing sugars and residual acids from the fermentation of wine, as a substrate for $C$. butyricum for the production of $\mathrm{H}_{2}$, the assimilation of citric acid and tartaric acid by $C$. butyricum was found to be weak, however the microbes absorbed a higher proportion of citric acid at lower concentrations. In this study $C$. butyricum was found to perform better with tartaric acid industrial glycerol gels 
than citric acid industrial glycerol gels. C. butyricum lacks all the necessary enzymes to completely metabolise citric acid, as it contains only NADP-specific isocitrate dehydrogenase $(\mathrm{ICDH})$ and not L-malate dehydrogenase $(\mathrm{MDH}) .{ }^{36}$ Another recent study found that $C$. butyricum is also missing succinate-CoA ligase and fumarate reductase enzymes, which are necessary for the citric acid cycle. ${ }^{37}$ As well as the higher quantity of citric acid present compared to tartaric acid in the glycerol gels, the inability of $C$. butyricum to metabolise citric acid via the same pathway used by E.coli may help to explain the negative effect of citric acid. As different bacteria exhibit differing abilities to metabolise natural acids, choice of the right acid as the catalyst for sol-gel immobilisation of the substrate, may result in optimised catalytic performance.

Table 1 Final pH, utilized glycerol I and 1,3-propanediol concentrations, specific growth rate $\left(\mu\left(h^{-1}\right)\right.$ and final optical density after $C$. butyricum cultivation with immobilized glycerol. Four different $\mathrm{K}_{2} \mathrm{HPO}_{4}$ and $\mathrm{KH}_{2} \mathrm{PO}_{4}$ combinations in $\mathrm{Y} 5$ media were tested.

\begin{tabular}{ccccccc}
$\begin{array}{c}\mathrm{K}_{2} \mathrm{HPO}_{4}: \\
\mathrm{KH}_{2} \mathrm{PO}_{4} \\
(\mathrm{~g} / \mathrm{L}: \mathrm{g} / \mathrm{L})\end{array}$ & Sample & Final pH & $\begin{array}{c}\text { Utilized } \\
\text { Glycerol I } \\
(\mathrm{g} / \mathrm{L})\end{array}$ & $\begin{array}{c}\text { Final } 1,3- \\
\mathrm{PDO}(\mathrm{g} / \mathrm{L})\end{array}$ & $\mu\left(\mathrm{h}^{-1}\right)$ & $\begin{array}{c}\text { Final } \\
\mathrm{OD}_{600 \mathrm{~nm}}\end{array}$ \\
\hline $0.5: 0.5$ & Control & $5.43 \pm 0.07$ & $16.59 \pm 0.52$ & $4.36 \pm 0.13$ & $0.25 \pm 0.01$ & $0.71 \pm 0.02$ \\
\hline & CA-A & $5.48 \pm 0.04$ & $6.87 \pm 0.58$ & $1.54 \pm 0.05$ & $0.10 \pm 0.02$ & $0.62 \pm 0.05$ \\
$5: 5$ & CA-B & $5.34 \pm 0.09$ & $3.94 \pm 0.56$ & $0.93 \pm 0.38$ & $0.09 \pm 0.01$ & $0.54 \pm 0.05$ \\
& TA-A & $5.40 \pm 0,02$ & $12.07 \pm 0.57$ & $2.84 \pm 0.16$ & $0.14 \pm 0.04$ & $0.72 \pm 0.04$ \\
& TA-B & $6.34 \pm 0.08$ & $0.6 \pm 1.01$ & $0.18 \pm 0.01$ & $0.02 \pm 0.01$ & $0.00 \pm 0.02$ \\
\hline \multirow{2}{*}{$10: 10$} & CA-A & $5.39 \pm 0.04$ & $4.14 \pm 0.59$ & $1.10 \pm 0.06$ & $0.09 \pm 0.01$ & $0.51 \pm 0.16$ \\
& CA-B & $5.34 \pm 0.05$ & $8.66 \pm 0.93$ & $1.21 \pm 0.03$ & $0.09 \pm 0.03$ & $0.60 \pm 0.07$ \\
& TA-A & $5.39 \pm 0.03$ & $12.55 \pm 0.46$ & $2.67 \pm 0.09$ & $0.14 \pm 0.02$ & $0.61 \pm 0.02$ \\
& TA-B & $6.27 \pm 0.07$ & $0.31 \pm 0.98$ & $0.18 \pm 0.01$ & $0.02 \pm 0.00$ & $0.00 \pm 0.02$ \\
\hline \multirow{2}{*}{$15: 0$} & CA-A & $5.53 \pm 0.09$ & $10.07 \pm 0.82$ & $2.84 \pm 0.10$ & $0.12 \pm 0.03$ & $0.47 \pm 0.04$ \\
& CA-B & $5.46 \pm 0.08$ & $12.78 \pm 0.49$ & $2.89 \pm 0.10$ & $0.12 \pm 0.02$ & $0.52 \pm 0.06$ \\
& TA-A & $5.52 \pm 0.05$ & $16.01 \pm 0.16$ & $4.10 \pm 0.11$ & $0.12 \pm 0.01$ & $0.67 \pm 0.06$ \\
& TA-B & $6.61 \pm 0.05$ & $0.89 \pm 0.91$ & $0.18 \pm 0.01$ & $0.01 \pm 0.01$ & $0.00 \pm 0.03$ \\
\hline & CA-A & $5.62 \pm 0.06$ & $9.20 \pm 0.60$ & $3.94 \pm 0.09$ & $0.13 \pm 0.02$ & $0.44 \pm 0.06$ \\
& CA-B & $5.61 \pm 0.04$ & $11.12 \pm 0.28$ & $4.10 \pm 0.07$ & $0.12 \pm 0.03$ & $0.57 \pm 0.03$
\end{tabular}


Conditions: $35^{\circ} \mathrm{C}, 120 \mathrm{rpm}, 5 \%(\mathrm{v} / \mathrm{v})$ inoculation, gel concentration $40 \mathrm{~g} / \mathrm{L}$, working volume $200 \mu \mathrm{l}$. Control experiment contained standard $\mathrm{Y} 5$ medium with $20 \mathrm{~g} / \mathrm{L}$ pure glycerol.

Release of glycerol C into the $C$. butyricum medium: Based on the previous results, tartaric acid was used as the catalyst to gel crude glycerol. Three different samples with different ratios of TEOS: glycerol (SI Table S5 entries 8-11), were tested for glycerol release and $\mathrm{pH}$ profile. To preserve the concentration of glycerol released at a concentration of approximately $20 \mathrm{~g} / \mathrm{L}$ with $40 \mathrm{~g} / \mathrm{L}$ of gel, the quantity of gel was increased for the ratios 1:0.5 and 1:0.25 to $80 \mathrm{~g} / \mathrm{L}$ and $160 \mathrm{~g} / \mathrm{L}$ respectively (SI, Figure S3). Adding double the quantity of 1:0.5 gel or quadruple the quantity of 1:0.25 gel gave a slightly higher glycerol dissolution compared to the 1:1 gel which gave approximately $20 \mathrm{~g} / \mathrm{L}$. The 1:0.1 ratio gel was determined to have too low a pH when scaled up to achieve the same glycerol concentration and so was not tested further.

The glycerol release profiles were similar for all purities of glycerol screened (P, I and C; S.I. Figures S1 \& S3, glycerol release). The major difference observed in the use of the three different glycerol samples was the level of acid contamination. In the $\mathrm{pH}$ experiments on crude glycerol it was necessary to increase the initial $\mathrm{pH}$ in the $\mathrm{Y} 5$ media higher than was required for the glycerol I gels (S.I. Figure S4 pH change over time). The $\mathrm{pH}$ was adjusted to $\mathrm{pH} 9,9.5$ and 10 for gels with TEOS: glycerol $\mathbf{C}$ ratios of 1:1, 1:0.5 and 1:0.25 respectively. This was required to reach conditions for bioactivity as adding a greater quantity of gel represented the addition of more acid to the bioprocess. The best $\mathrm{pH}$ profile for $C$. butyricum cultivation was obtained with the 1:1 gel, which was selected for further testing.

Attempts to Cultivate $C$. butyricum using glycerol $C$ gels: The use of crude glycerol $\mathbf{C}$ was observed to completely inhibit the biocatalytic activity of $C$. butyricum, (Figure 6, S.I. Tables S5 \& S7). No cell growth was observed in any of the experiments. The entrapment of the crude glycerol in a silica matrix did not protect C. butyricum from the toxicity of glycerol C. 


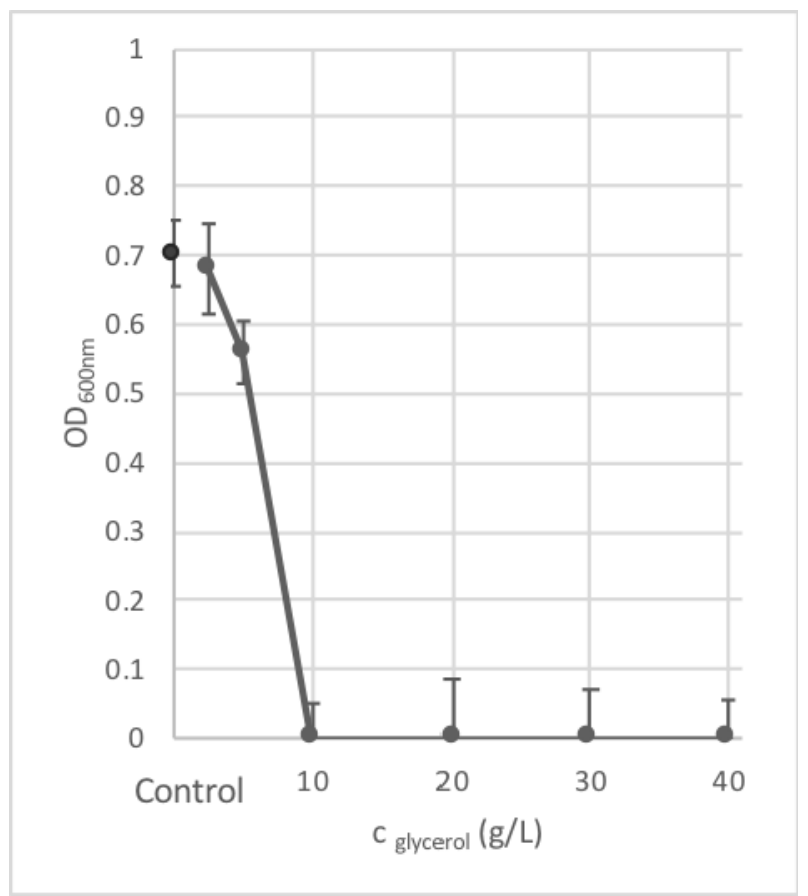

Figure 6. Cell death, Optical Density measurements when crude glycerol $\mathbf{C}$ was fed to $C$. butyricum.

\section{The use of glycerol gels to feed $E$. coli}

E. coli was chosen as the second testing model due to the potential of genetically engineered $E$. coli to produce recombinant enzymes from crude glycerol. These are high value products and could warrant the use of pure (P), purified industrial (I) or crude (C) glycerol. As the optimised medium for E.coli cultivation is different from that of $C$. butyricum, the glycerol release and $\mathrm{pH}$ change experiments were performed again into the optimised semi-defined medium. Pure glycerol release and $\mathrm{pH}$ change into semi-defined medium was prepared with an increased initial $\mathrm{pH}$ of 8.7 and 9.2 for TA and CA gels respectively (S.I. Table S3). Gel quantities of $40 \mathrm{~g} / \mathrm{L}$ glycerol achieved approximately 15-20 $\mathrm{g} / \mathrm{L}$ glycerol dissolution into the fermentation medium. The citric acid catalysed glycerol gels yielded a lower concentration of glycerol as there was a higher proportion of acid in these gels (S.I. Figure S5). The $\mathrm{pH}$ buffering capacity was much higher for the optimised E. coli BL21 medium compared to the Y5 medium used for $C$. butyricum, and the $\mathrm{pH}$ decrease from the gels in the E. coli medium wasn't as significant (S.I. Figure S4 c.f. Figure S6). Glycerol release was comparable in terms of final concentrations obtained, although in this case, the speed of release was marginally faster. 
Cultivation of E. coli using glycerol P gels: The micro-cultivation of E.coli with $40 \mathrm{~g} / \mathrm{L}$ immobilized glycerol P (S.I. Table S3), was tested with different amounts of $\mathrm{NaH}_{2} \mathrm{PO}_{4}$ and $\mathrm{Na}_{2} \mathrm{HPO}_{4}$ (Table 2). The glycerol utilized and the final optical density was highest for both CA and TA gels with the standard $\mathrm{NaH}_{2} \mathrm{PO}_{4}$ concentration as used in the control experiment (2.8 g/L). E.coli in the control experiment utilized $4.03 \mathrm{~g} / \mathrm{L}$ glycerol whilst E.coli with TA gels utilized $7.19 \mathrm{~g} / \mathrm{L}$ of glycerol, although with a slightly lower final optical density of 0.79 compared to 0.92 ; indicating less cell growth with TA gels compared to the non-immobilised pure glycerol control. The CA gels also utilised more glycerol compared to the control reaction, using $4.11 \mathrm{~g} / \mathrm{L}$ glycerol and achieving an optical density of 0.69 . This is significant as the control experiment contained $30 \mathrm{~g} / \mathrm{L}$ of pure glycerol, whilst the gels at $40 \mathrm{~g} / \mathrm{L}$ released 17-20 g/L for the CA and TA gels respectively (S.I. Figure S5). Although the release of glycerol from the CA and TA gels allowed E.coli to utilise more glycerol, the lower concentration and speed of the release of glycerol is possibly why the specific growth rates in these reactions were slower. When $5 \mathrm{~g} / \mathrm{L} \mathrm{NaH} \mathrm{PO}_{4}$ and $2.8 \mathrm{~g} / \mathrm{L} \mathrm{Na} 2 \mathrm{HPO}_{4}$ were used with the CA and TA gels substantially less glycerol was utilised by E.coli, as well as giving a lower final optical density value indicating lower cell growth. In contrast to the experiments with $2.8 \mathrm{~g} / \mathrm{L} \mathrm{NaH} \mathrm{PO}_{4}$, the CA gels performed better than the TA gels, utilising higher concentrations of glycerol with higher cell growth.

Table 2. Final $\mathrm{pH}$, utilized glycerol concentration, specific growth rate and final optical density after $E$. coli cultivation with immobilized glycerol P ( $40 \mathrm{~g} / \mathrm{L}$ gel).

\begin{tabular}{cccccc}
$(\mathrm{g} / \mathrm{L})$ & sample & Final $\mathrm{pH}$ & $\begin{array}{c}\text { Utilized } \\
\text { Cglycerol }(\mathrm{g} / \mathrm{L})\end{array}$ & $\mu\left(\mathrm{h}^{-1}\right)$ & $\begin{array}{c}\text { Final } \\
\mathrm{OD}_{600 \mathrm{~nm}}\end{array}$ \\
\hline 2.8 & Control & $6.55 \pm 0.09$ & $4.03 \pm 0.57$ & $1.62 \pm 0.02$ & $0.92 \pm 0.03$ \\
\cline { 2 - 6 } $\mathrm{NaH}_{2} \mathrm{PO}_{4}$ & $\mathrm{CA}$ & $6.74 \pm 0.03$ & $4.11 \pm 0.97$ & $0.92 \pm 0.15$ & $0.69 \pm 0.11$ \\
& TA & $6.82 \pm 0.03$ & $7.19 \pm 2.20$ & $0.85 \pm 0.07$ & $0.79 \pm 0.14$ \\
\hline 5 & CA & $6.68 \pm 0.04$ & $2.67 \pm 0.84$ & $0.76 \pm 0.07$ & $0.71 \pm 0.11$ \\
$\mathrm{NaH}_{2} \mathrm{PO}_{4}$ & TA & $6.79 \pm 0.02$ & $0.85 \pm 2.16$ & $0.49 \pm 0.21$ & $0.61 \pm 0.17$ \\
\hline 2.8 & CA & $6.40 \pm 0.06$ & $1.29 \pm 0.63$ & $0.79 \pm 0.18$ & $0.79 \pm 0.09$ \\
$\mathrm{Na}_{2} \mathrm{HPO}_{4}$ & TA & $6.68 \pm 0.03$ & $0.17 \pm 3.41$ & $0.73 \pm 0.14$ & $0.41 \pm 0.07$ \\
\hline
\end{tabular}


Conditions: $37^{\circ} \mathrm{C}, 240 \mathrm{rpm}, 2.5 \%(\mathrm{v} / \mathrm{v})$ inoculation, working volume $200 \mu \mathrm{l}$, gel concentration $40 \mathrm{~g} / \mathrm{L}$. Control experiment contained semi-defined medium with $30 \mathrm{~g} / \mathrm{L}$ of pure glycerol and $2.8 \mathrm{~g} / \mathrm{L}$ $\mathrm{NaH}_{2} \mathrm{PO}_{4}$.

Compatibility of crude glycerol gels with E.coli; cultivation of $E$. coli using glycerol C gels: The standard concentration of $\mathrm{NaH}_{2} \mathrm{PO}_{4}(2.8 \mathrm{~g} / \mathrm{L})$ was used in experiments with glycerol $\mathrm{C}$ gels. Both CA and TA catalysed crude glycerol C gels were screened. Gels with TEOS: glycerol ratio 1:1 were used and concentrations were tested at 20,40,60 and $80 \mathrm{~g} / \mathrm{L}$ of gels (representing approximately $10,20,30$ and $40 \mathrm{~g} / \mathrm{L}$ of crude glycerol respectively).

Experiments with conventional (non-immobilised) crude glycerol $\mathbf{C}$ presented no cell growth above $10 \mathrm{~g} / \mathrm{L}$ of crude glycerol, and very weak growth at lower concentrations (S.I. Figure S7).

E.coli bacteria were able to grow and utilise glycerol $\mathbf{C}$ when delivered via a gel (Table 3 ). In the control reaction, which used $30 \mathrm{~g} / \mathrm{L}$ pure glycerol, the E.coli utilised $4.03 \mathrm{~g} / \mathrm{L}$ glycerol with a final optical density of 0.94 . The best performing gel was the CA glycerol $\mathbf{C}$ gel at 20 $\mathrm{g} / \mathrm{L}$, for which 3.54 glycerol was utilised to give a final optical density of 0.83 . This shows that similar quantities of glycerol could be used by E.coli from the dissolution of crude glycerol from the gels, in comparison to the pure glycerol control reaction. The lower cell growth, and specific growth rate, is likely to be due to the lower concentrations of glycerol, $20 \mathrm{~g} / \mathrm{L}$ gel concentration typically yielded approximately $10 \mathrm{~g} / \mathrm{L}$ crude glycerol, in comparison to the optimised control, which contained $30 \mathrm{~g} / \mathrm{L}$ pure glycerol. Increasing the gel to 40,60 and $80 \mathrm{~g} / \mathrm{L}$ gradually decreased cell growth. From these experiments, it is unclear whether this was caused by a higher concentration of released impurities (due to higher gel concentrations), by the decreased $\mathrm{pH}$ due to the higher quantities of acid from the gels, or by a combination of both factors. The TA gels were far less successful than the CA gel. This is the opposite of what was found to occur with the acids from the immobilised glycerol I with C. butyricum. This can be explained as the optimised fermentation medium for E.coli contains citric acid, which is necessary for the citric acid cycle in E. coli, ${ }^{38,39}$ and therefore the quantities present in the gel do not have as dramatic a negative effect on the E.coli as the addition of L-(+)-tartaric acid. 
These results suggest that the silica gel immobilization of crude glycerol $\mathbf{C}$ at gel concentration $20 \mathrm{~g} / \mathrm{L}$ supported cell growth and utilisation of glycerol as a carbon source. Gel-fed E. coli cells exhibited a higher tolerance to crude glycerol $\mathbf{C}$ than cells presented with glycerol C in the liquid phase. (S.I. Figure S7). This result shows that the use of silica sol-gel to immobilise crude glycerol is a viable one-step technique to turn a toxic, waste substrate in to a useable substrate without the need for purification.

Table 3. Final $\mathrm{pH}$, utilized glycerol concentration, specific growth rate and final optical density after $E$. coli cultivation with immobilized glycerol C (CA 1:1 and TA 1:1) and $2.8 \mathrm{~g} / \mathrm{L}$ $\mathrm{NaH}_{2} \mathrm{PO}_{4}$.

\begin{tabular}{cccccc}
$\mathrm{C}_{\mathrm{Gel}}(\mathrm{g} / \mathrm{L})$ & Sample & Final $\mathrm{pH}$ & $\begin{array}{c}\text { Utilized } \\
\mathrm{C}_{\text {glycerol }}(\mathrm{g} / \mathrm{L})\end{array}$ & $\mu\left(\mathrm{h}^{-1}\right)$ & $\begin{array}{c}\text { Final } \\
\mathrm{OD}_{600 \mathrm{~nm}}\end{array}$ \\
\hline- & Control & $6.20 \pm 0.07$ & $4.03 \pm 0.65$ & $1.72 \pm 0.01$ & $0.94 \pm 0.09$ \\
\hline 20 & CA & $6.70 \pm 0.09$ & $3.54 \pm 1.16$ & $0.37 \pm 0.20$ & $0.83 \pm 0.02$ \\
& TA & $6.47 \pm 0.03$ & $1.41 \pm 0.54$ & $0.55 \pm 0.25$ & $0.76 \pm 0.03$ \\
\hline \multirow{2}{*}{40} & CA & $6.59 \pm 0.04$ & $3.35 \pm 1.69$ & $0.40 \pm 0.18$ & $0.56 \pm 0.02$ \\
& TA & $6.23 \pm 0.07$ & $1.31 \pm 0.64$ & $0.78 \pm 0.02$ & $0.51 \pm 0.04$ \\
\hline \multirow{2}{*}{60} & CA & $5.34 \pm 0.11$ & $1.74 \pm 1.25$ & $0.37 \pm 0.04$ & $0.22 \pm 0.02$ \\
& TA & $5.32 \pm 0.09$ & $0.33 \pm 2.17$ & $0.46 \pm 0.33$ & $0.36 \pm 0.09$ \\
\hline \multirow{2}{*}{80} & CA & $4.72 \pm 0.28$ & $0.65 \pm 1.76$ & $0.00 \pm 0.00$ & $0.00 \pm 0.00$ \\
& TA & $4.84 \pm 0.06$ & $0.32 \pm 1.66$ & $0.00 \pm 0.00$ & $0.00 \pm 0.00$
\end{tabular}

Conditions: $37^{\circ} \mathrm{C}, 240 \mathrm{rpm}, 2.5 \%(\mathrm{v} / \mathrm{v})$ inoculation, working volume $200 \mu \mathrm{l}$, gel concentration 20,40 , $60,80 \mathrm{~g} / \mathrm{L}$. Control experiment contained semi-defined medium with $30 \mathrm{~g} / \mathrm{L}$ of pure glycerol and 2.8 $\mathrm{g} / \mathrm{L} \mathrm{NaH}_{2} \mathrm{PO}_{4}$.

\section{Experimental Section}

Materials and methods

Three purities of glycerol were used, Glycerol P (pure) Glycerol I (industrial) and Glycerol C (crude) Glycerol P ( $\geq 99.5 \%$ w, Sigma-Aldrich), Glycerol I (Industrial) (97 \% purity supplied from Megara) and glycerol C (crude) (76.9 \% purity, ENEA, crude glycerol).

$\mathrm{CH}_{3} \mathrm{OH}$ ( $\geq 99.9 \%$, CHROMASOLV, for HPLC, Sigma-Aldrich), $\mathrm{C}_{6} \mathrm{D}_{6}(\geq 99.0 \% w$, Aldrich), ethanol ( $\geq 99.0 \%$, laboratory supplies and instruments Itd.), citric acid monohydrate ( $\geq 99.7$ 
$\%$, Atom scientific), TEOS ( $\geq 97 \%, \mathrm{TCI}$ UK), L-(+)-tartaric acid (99 \% Alfa Aesar), were used as received.

Silica glycerol gels were prepared as detailed in S1.2, S1.3, S1.4 and S2.1. The cultivation media were prepared as described in S2.2 (Y5 medium) and S2.3 (semi-defined medium). The trace element solution is detailed in S2.4. Glycerol release experiments were carried out in a laboratory thermomixer with standard working volume $1 \mathrm{ml}$ as detailed in $\mathbf{S 2 . 5}$. Cultivation experiments were carried out as described in S2.6, S2.7, S2.8 and S2.9. Experiments with E.Coli were performed as detailed in S2.10 and S2.11.

\section{Conclusions}

All the silica glycerol gels reported here were able to deliver glycerol into the fermentation media for the bacteria. Natural acids could be used as the catalyst for silica gel formation from TEOS. The acid leach from the glycerol gels could be balanced to some extent by utilising higher concentrations of phosphate buffer. At higher acid concentrations this is likely to have resulted in non-ideal conditions for $C$. butyricum activity. Using $C$. butyricum promising results were found from the use of tartaric acid catalysed immobilised industrial (97\% purity) glycerol in comparison to the non-immobilised pure glycerol control reaction. However, the immobilised crude glycerol (C $76.9 \%$ purity) gels were found to be completely incompatible with $C$. butyricum, and the toxicity using the gels was found to be similar to the toxicity of equivalent concentrations of crude glycerol C fed as a solution $(10 \mathrm{~g} / \mathrm{L}$ was found to inhibit cell growth).

The use of immobilised crude glycerol gels was more successful with E. coli. E. coli bacteria utilised glycerol C from the $20 \mathrm{~g} / \mathrm{L}$ citric acid catalysed gels with uptake of glycerol and cell growth only slightly lower than the optimised control using pure glycerol. E.coli was found to have a preference for the citric acid catalysed crude glycerol gels over the tartaric acid catalysed crude glycerol gels. This is consistent with the fact that the optimised fermentation medium for E.coli already contains citric acid.

We have demonstrated that glycerol containing silica gels effectively deliver substrate in a controlled manner to fermentation bioprocesses. The gel is formed in a simple one-step procedure which can transform a crude bio-renewable chemical from a toxic poison into a non-toxic feedstock. The most remarkable results were obtained using crude glycerol 
entrapped in a citric acid catalyzed silica gel fed to E.coli. These microbes are suitable for recombinant protein production.

In our delivery system we have used TEOS as the starting material for silica, and replaced the acid (catalyst) component and solvent of the sol-gel process with food acids and crude waste glycerol, which acts as the solvent for the reaction, the template, and the substrate for biocatalysis. The materials are produced at room temperature without the need for additional solvents. The source of TEOS is an important consideration; TEOS can be

produced by the direct reaction of ethanol with silicon over a catalyst. ${ }^{40-44}$ The production of silicon is still a relatively high-energy process however, this method removes the need for the use of chlorinated reagents and the ethanol could be derived from renewable resources (bioethanol). In the life cycle the production of waste silica is another important factor; if pure silica wastes are deposited in soils or in aquatic environments, silica dissolution occurs via erosion, in the presence of water (silicic acid formed). ${ }^{45}$ The utilisation of silica is observed in biological systems such as fungi, bacteria ${ }^{46}$ or diatoms. ${ }^{47}$ It has been debated that the emission of $\mathrm{SiO}_{2}$ by human endeavour contributes only a small percentage to changes in global silicon fluctuations, and has a small environmental impact, because of the high concentrations found in nature (silica in soils and aquatic environments). ${ }^{48}$ The material we present here essentially comprises of $\mathrm{SiO}_{2}$, glycerol and food acids. That being said once the gel has been in contact with the whole cell culture a pre-treatment to sterilise the cells could be required before waste production. Chemical recycling of silica is also possible; dissolution in alkaline solution would produce aqueous silicates, which can be reused. ${ }^{49,50}$

\section{Acknowledgements}

This work was supported by GRAIL (Grant agreement no: 613667), project co-financed by the European Commission under the $7^{\text {th }}$ Framework Programme, DEL (Department of Employment and Learning) Northern Ireland studentship (KMB) and the Slovak Research and Development Agency [contract no. DO7RP-0045-12]. This article was created with the support of the Ministry of Education, Science, Research and Sport of the Slovak Republic within the Research and Development Operational Programme for the project "University Science Park of STU Bratislava", ITMS 26240220084. We wish to thank Carles Estévez for useful discussions, and Megara resins and ENEA for providing glycerol samples. 


\section{References}

1. Zajkoska, P.; Rosenberg, M.; Heath, R.; Malone, K.J.; Stloukal R.; Turner, N.J.; Rebroš, M. Immobilised whole-cell recombinant monoamine oxidase biocatalysis. Appl. Microbiol. Biotechnol. 2015, 99, 1229-1236. DOI: 10.1007/s00253-014-5983-1.

2. Rebroš, M.; Lipták. L.; Rosenberg, M.; Bučko, M.; Gemeiner, P. Biocatalysis with Escherichia coli-overexpressing cyclopentanone monooxygenase immobilized in polyvinyl alcohol gel. Lett. Appl. Microbiol. 2014, 58, 556-563. DOI: 10.1111/lam.12227.

3. Dong, T. T.; Gong, J. S.; Gu, B. C.; Zhang, Q.; Li, H.; Lu, Z. M.; Lu, M. L.; Shi, J. S.; Xu, Z. H. Significantly enhanced substrate tolerance of Pseudomonas putida nitrilase via atmospheric and room temperature plasma and cell immobilization. Bioresource Technol. 2017, 244, 1104-1110. DOI: 10.1016/j.biortech.2017.08.039.

4. Meyer, L. E.; Langermannm, J.; Kragl, U. Recent developments in biocatalysis in multiphasic ionic liquid reaction systems. Biophys. Rev. 2018, 10, 901-910. DOI: 10.1007/s12551-018-0423-6

5. Liu, X.-H.; Rebros, M.; Dolejš , I.; Marr, A. C. Designing Ionič Liquids for the Extraction of Alcohols from Fermentation Broth: Phosphonium Alkanesulfonates, Solvents for Diol Extraction. ACS Sustainable Chem. Eng. 2017, 5, 8260-8268. DOI: 10.1021/acssuschemeng.7b01934

6. Zhao, G.; Zhou, L.; Li, Y.; Liu, X.; Ren, X.; Liu, X. Enhancement of phenol degradation using immobilized microorganisms and organic modified montmorillonite in a twophase partitioning bioreactor. J. Hazard. Mater. 2009, 169, 402-410. DOI: 10.1016/j.jhazmat.2009.03.110

7. Tan, H. W.; Aziz, A. R. A.; Aroua, M. K. Glycerol production and its applications as a raw material: A review. Renew. Sust. Energ. Rev. 2013, 27, 118-127. DOI: 10.1016/j.rser.2013.06.035

8. Tacias-Pascacio, V. G.; Virgen-Ortiz, J. J.; Jimenez-Perez, M.; Yates, M.; TorrestianaSanchez, B.; Rosales-Quintero, A.; Fernandez-Lafuente, R. Evaluation of different lipase biocatalysts in the production of biodiesel from used cooking oil: Critical role of the immobilization support. Fuel, 2017, 200, 1-10. DOI: 10.1016/j.fuel.2017.03.054

9. Barbirato, F.; Himmi, E. H.; Conte, T.; Bories A. 1,3-propanediol production by fermentation: An interesting way to valorize glycerin from the ester and ethanol industries. Ind. Crop. Prod, 1998, 7, 281-289. DOI: 10.1016/S0926-6690(97)00059-9

10. Chatzifragkou, A.; Dietz, D.; Komaitis, M.; Zeng A. P.; Papanikolaou, S. Effect of biodiesel-derived waste glycerol impurities on biomass and 1,3-propanediol production of Clostridium butyricum VPI 1718, Biotechnol. and Bioeng. 2010, 107, 7684. DOI: https://doi.org/10.1002/bit.22767

11. Papanikolaou, S. 2009. Microbial conversion of glycerol into 1,3-propanediol: Glycerol assimilation, biochemical events related with 1,3-propanediol biosynthesis and biochemical engineering of the process. In: Aggelis, G, editor. Microbial conversions of raw glycerol. New York: Nova Science Publishers, Inc. p 137-168. (ISBN: 9781606923924)

12. Johnson, D. T.; Taconi K. A. The glycerin glut: Options for the value-added conversion of crude glycerol resulting from biodiesel production. Environ. Prog. 2007, 26: 338348. DOI: https://doi.org/10.1002/ep.10225 
13. Willke T.; Vorlop, K. D.; Industrial bioconversion of renewable resources as an alternative to conventional chemistry. Appl. Microbiol. Biotechnol. 2004, 66, 131-142. DOI: 10.1007/s00253-004-1733-0.

14. Liu. S.; Rebroš, M.; Stephens, G.; Marr, A. C. Adding value to renewables: a one pot process combining microbial cells and hydrogen transfer catalysis to utilise waste glycerol from biodiesel production Chem. Commun. 2009, 2308-2310. DOI: 10.1039/B820657K

15. Wang, Y-M; Lorenzini, F.; Rebros, M.; Saunders, G. C.; Marr, A. C. Combining bio and chemo-catalysis for the conversion of bio-renewable alcohols: homogeneous iridium catalysed hydrogen transfer initiated dehydration of 1,3-propanediol to aldehydes. Green Chem. 2016, 18, 1751-1761. DOI: 10.1039/C5GC02157J

16. Varrone, C.; Floriotis, G.; Heggeset T. M. B.; Le S. B.; Markussen, S.; Skiadas I. V.; Gavala, H. N. Continuous fermentation and kinetic experiments for the conversion of crude glycerol derived from second-generation biodiesel into 1,3 propanediol and butyric acid. Biochem. Eng. J. 2017, 128, 149-161. DOI: 10.1016/j.bej.2017.09.012

17. Carvalho, M.; Matos, M.; Roca, C.; Reis, M. A. Succinic acid production from glycerol by Actinobacillus succinogenes using dimethylsulfoxide as electron acceptor, New Biotechnol. 2014, 31, 133-139. DOI: 10.1016/j.nbt.2013.06.006.

18. Stepanov, N.; Efremenko, E. Immobilised cells of Pachysolen tannophilus yeast for ethanol production from crude glycerol, New Biotechnol. 2017, 34, 54-58. DOI: 10.1016/j.nbt.2016.05.002.

19. Sittijunda, S.; Reungsang, A. Fermentation of hydrogen, 1,3-propanediol and ethanol from glycerol as affected by organic loading rate using up-flow anaerobic sludge blanket (UASB) reactor, Int. J. Hydrog Energy, 2017, 42, 45,27558-27569. DOI: 10.1016/j.ijhydene.2017.05.149

20. Krasňan, V.; Plž, M.; Marr, A. C.; Markošová, K.; Rosenberg M.; Rebroš, M. Intensified crude glycerol conversion to butanol by immobilized Clostridium pasteurianum. Biochem. Eng. J. 2018, 134, 114-119. DOI: 10.1016/j.bej.2018.03.005

21. Samul, D.; Leja, K.; Grajek, W. Impurities of crude glycerol and their effect on metabolite production. Ann. Microbiol. 2014, 64, 891-898. DOI: 10.1007/s13213-0130767-x

22. Lacroix, S. D.; Pennycook, A.; Liu, S.; Eisenhart, T. T.; Marr, A. C. Amination and dehydration of 1,3-propanediol by hydrogen transfer: reactions of a bio-renewable platform chemical, Catal. Sci. Technol. 2012, 2, 288-290. DOI: 10.1039/C1CY00339A

23. Ma, Y.-Y.; Wang, Y.-M.; Morgan, P. J.; Jackson, R. E.; Liu, X.-H.; Saunders, G. C.; Lorenzini, F.; Marr, A. C. Designing effective homogeneous catalysis for glycerol valorisation: selective synthesis of a value-added aldehyde from 1,3-propanediol via hydrogen transfer catalysed by a highly recyclable, fluorinated $\mathrm{Cp} * \operatorname{Ir}(\mathrm{NHC})$ catalyst, Catal. Today, 2018, 307, 248-259. DOI: 10.1016/j.cattod.2017.09.036

24. Casali, S.; Gungormusler, M.; Bertin, L.; Fava, F.; Azbar, N. Development of a biofilm technology for the production of 1,3-propanediol (1,3-PDO) from crude glycerol. Biochem. Eng. J. 2012, 64, 84-90. DOI: 10.1016/j.bej.2011.11.012

25. González-Pajuelo, M.; Andrade, J. C.; Vasconcelos, I. Production of 1,3-propanediol by Clostridium butyricum VPI 3266 using a synthetic medium and raw glycerol. J. Ind. Microbiol. Biotechnol. 2004, 31(4), 442-446. DOI: 10.1007/s10295-004-0168-Z 
26. Saint-Amans, S.; Girbal, L.; Andrade, J.; Ahrens, K.; Soucaille, P. Regulation of carbon and electron flow in Clostridium butyricum VPI 3266 grown on glucose-glycerol mixtures. J. Bacteriol. 2001, 183(5), 1748-175. DOI: 10.1128/JB.183.5.1748-1754.2001

27. Da Silva, G. P.; Mack, M.; Contiero, J. Glycerol: a promising and abundant carbon source for industrial microbiology. Biotechnol. Adv. 2009, 27, 30-39. DOI: 10.1016/j.biotechadv.2008.07.006.

28. Colin, T.; Bories, A.; Lavigne, C.; Moulin, G. Effects of acetate and butyrate during glycerol fermentation by Clostridium butyricum, Curr. microbiol. 2001, 43, 238-243. DOI: 10.1007/s002840010294

29. Thompson, J. C.; He, B. B.; Characterization of Crude Glycerol from Biodiesel Production from Multiple Feedstocks. Appl. Eng. Agric. 2006, 22, 261-265. DOI: 10.13031/2013.20272

30. Athalye, S. K.; Garcia, R. A.; Wen, Z. J. Agric. Food Chem. 2009, 57, 2739-2744. DOI: 10.1021/jf803922w

31. Wischral, D.; Zhang, J.; Cheng, C.; Lin, M.; Souza, L.; Pessoa, F.; Pereira Jr., N.; S.Yang, T. Production of 1,3-propanediol by Clostridium beijerinckii DSM 791 from crude glycerol and corn steep liquor: Process optimization and metabolic engineering, Bioresour. Technol. 2016. 212, 100-110. DOI: 10.1016/j.biortech.2016.04.020

32. Gonzalez-Pajuelo, M.; Andrade, J. C.; Vasconcelos, I. J. Ind. Microbiol. Biotechnol. 2004, 31, 442-446. DOI: 10.1007/s10295-004-0168-z

33. Xu, J. Y.; Zhao, X. B.; Wang, W. C.; Du, W.; Liu, D. H. Microbial conversion of biodiesel byproduct glycerol to triacylglycerols by oleaginous yeast Rhodosporidium toruloides and the individual effect of some impurities on lipid production. Biochem. Eng. J. 2012, 65, 30-36. DOI: 10.1016/j.bej.2012.04.003

34. Gerson, D. F.; Kole, M. M.; Ozum B.; Oguztoreli, M. N. Substrate concentration control in bioreactors. Biotechnol. Gene. Eng. Rev. 1988, 6, 67-150. DOI: 10.1080/02648725.1988.10647846

35. Krysteva, M.; Lalov, I.; Beschkov, V. Acceleration and increase of hydrogen production by simultaneous fermentation of Clostridium butyricum and Rhodobacter sphaeroides on wine-vinasse substrate, Bulg. Chem. Commun. 2010, 42, 46-50. http://bcc.bas.bg/BCC_Access_Full-Text.html

36. Kotze, J. P. Glycolytic and Related Enzymes in Clostridial Classification, Am. Soc. Microbiol. 1969, 18, 744-747.

https://aem.asm.org/content/aem/18/5/744.full.pdf

37. Serrano-Bermúdez, L. M.; González-Barrios, A. F.; Maranas, C. D;. Montoya, D. Clostridium butyricum maximizes growth while minimizing enzyme usage and ATP production: metabolic flux distribution of a strain cultured in glycerol. BMC Systems Biology, 2017, 11, 58. DOI: 10.1186/s12918-017-0434-0

38. Green, J.; Guest, J. R. The Citric Acid Cycle and Oxygen-Regulated Gene Expression in Escherichia coli. In: Busby S.J.W., Thomas C.M., Brown N.L. (eds.) Molecular Microbiology. NATO ASI Series (Series H: Cell Biology), 1998, 103. 17-18. Springer, Heidelberg Berlin. DOI: 10.1007/978-3-642-72071-0_2

39. Guest, J. R.; Russell, G. C. in Current Topics in Cellular Regulation, eds. E. R. Stadtman and P. B. Chock, Academic Press, 1992, 33, 231-247. DOI: 10.1016/B978-0-12-1528331.50018-6

40. Rochow, E. G. Methyl Silicate from Silicon and Methanol. J. Am. Chem. Soc. 1948, 70, 2170-2171. DOI: 10.1021/ja01186a051 
41. US Pat. 2473, 260, June 14, 1949.

42. Newton, W. E.; Rochow, E. G. Direct synthesis of organic derivatives of silicon using nonhalogenated organic compounds Inorg. Chem. 1970, 9, 1071-1075. DOI: 10.1021/ic50087a014

43. US Pat. 3641077, 1972.

44. Krylova, I.V.; Egorov, M.P.; Nefedov, O.M. Reaction of silicon with alcohols in autoclave. Russ. Chem. Bull. 2017, 66, 260-266. DOI: DOI:doi.org/10.1007/s11172017-1726-7

45. Zhmud, B. V.; House, W. A.; Denison, F H. Release kinetics and concentration profile of dissolved silicon in compacted sediments. J. Chem. Soc., Faraday Trans. 1997, 93, 3473-3478. DOI: 10.1039/a702059g

46. Bennett, P. C.; Rogers, J. R.; Choi, W. J.; Hiebert F. K. Silicates, Silicate Weathering, and Microbial Ecology, Geomicrobiol. J. 2001, 18, 3-19, DOI: 10.1080/01490450151079734

47. Gautier, C.; Coradin, T.; Livage, J. Lopez, P. J. Sol-gel encapsulation extends diatom viability and reveals their silica dissolution capability. Chem. Commun. 2006, 0, 46114613. 10.1039/B609121K

48. Van Dokkum, H. P.; Hulskotte, J. H. J.; Kramer, K. J. M.; Wilmot, J. Emission, Fate and Effects of Soluble Silicates (Water glass) in the Aquatic Environment. Environ. Sci. Technol. 2004, 38, 515-521. DOI: http://pubs.acs.org/doi/abs/10.1021/es0264697.

49. Alam, Q.; Hendrix, Y.; Thijs, L.; Lazaro, A.; Schollbach, K.; Brouwers, H. J. H. Novel low temperature synthesis of sodium silicate and ordered mesoporous silica from incineration bottom ash. J. Clean. Prod. 2019, 211, 20, , 874-883. DOI: https://doi.org/10.1016/i.jclepro.2018.11.173.

50. Baccile, N.; Babonneau, F.; Thomas, B.; Coradin, T. Introducing ecodesign in silica solgel materials. J. Mater. Chem. 2009, 19, 8537-8559. DOI: 10.1039/b91 1123a. 
Figure for TOC entry:

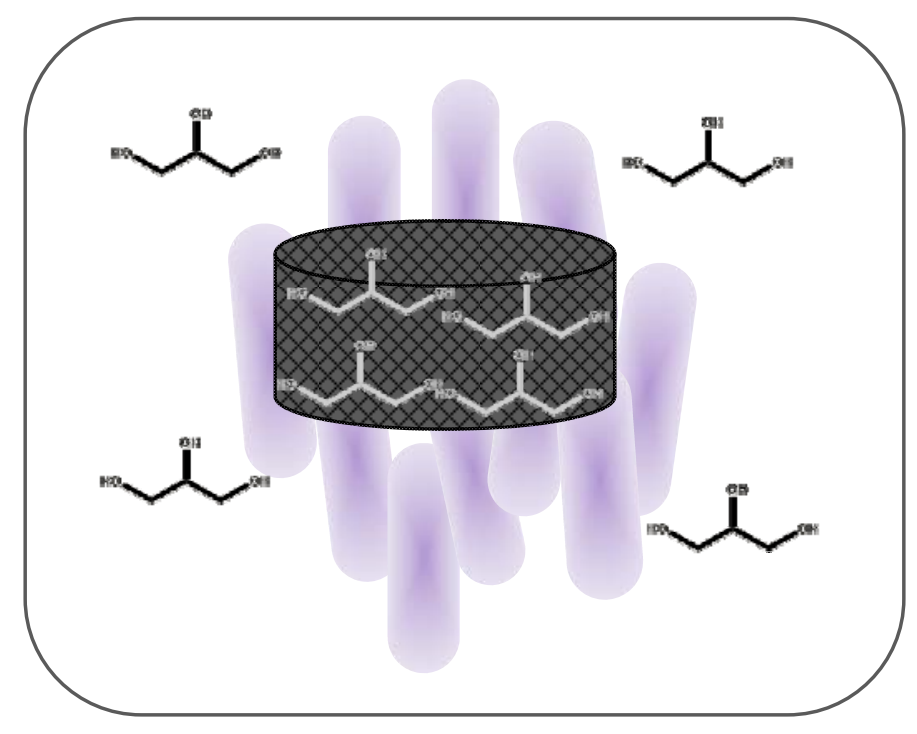

Synopsis. Glycerol gels provide a method of delivering waste glycerol from biodiesel production to biocatalysts without the need for glycerol pre-purification. 